\title{
John Locke at the Polish Brothers school
}

\begin{abstract}
The goal of this article is to show the influence of Polish Brothers on the British philosopher John Locke. As an example, it will be point out the influence of Polish Brothers on the very influential text of Locke's A Letter Concerning Toleration and other writings of this philosopher. Only in recent years it was accepted that Locke borrowed the concepts like tolerance and rationality of religious beliefs from Polish Brothers.
\end{abstract}

Keywords: John Locke, Polish Brothers, tolerance, rationality of religious beliefs

howing the influence of the Polish Brothers on other groups of religious thinkers
is an important proof of the gradual emancipation of the marginal and persecuted religious group. It is also an example of the process of shaping the values of tolerance and religious freedom, fundamental for our civilization. It can be shown by analyzing the presence of the views of Polish Brothers in the context of Europe divided by religious wars. The indicated values, although in Europe were contested in the 17th and 18th centuries, were adopted in North America. In the previous literature on the subject, there was talk about the influence of John Locke. My goal is to show the influence of Polish Brothers on the British philosopher. As an example, I would like to point out the influence of Polish Brothers on the very influential text of Locke's A Letter Concerning Toleration and other writings of this philosopher. 


\section{Preliminary remarks}

The perception of the past through the prism of clearly defined definitions such as the Middle Ages, Renaissance, Baroque or Enlightenment has its advantages because it organizes our thinking and facilitates understanding of the mechanisms that guide civilization development. However, it also conceals the danger of overly sharp opposing phenomena that are not always dichotomous. And so, the Middle Ages, staring at the afterlife and opposed to the human-centered Renaissance, become a dark age and hostile to humanism, and the baroque entangled in religious disputes, clashed with enlightenment rationality, is sometimes seen as irrational and quite unpredictable.

Fortunately, for more than a dozen years in the humanities we are increasingly moving away from such unequivocal distinction and increasingly willingly look for what connects individual epochs. An example is a book by Jack Goody problematizing the Renaissance. ${ }^{1}$ Another example is two volumes of studies devoted to the place of Jesuits in Polish culture indicating their participation in the creation of the Enlightenment breakthrough at the end of the 18th century. ${ }^{2}$ I would like to pay attention to such unobvious connections of the philosopher perceived as a representative of the English Enlightenment with radical reformers of the 16th and 17th centuries who developed their views most fully in the Polish-Lithuanian Commonwealth.

Relationships of John Locke (1632-1704) with the thought of Polish Brothers, although they were noticed quite early, are neither simple nor obvious. Yes, opponents of the philosopher eagerly attributed them to him, and one of them, contemporary to Locke and particularly hostile to him, Anglican priest John Edwards in his book Socinianism Unmask'd, published in 1697 called him simply "Rakovian rabbi." ${ }^{3}$ He himself strongly opposed these relationships, which the author of the monograph devoted to him described as “mental reservation," recognizing that religious views are his private matter, from which he does not have to explain in public. ${ }^{4}$

${ }^{1}$ J. Goody, Renaissances. The One or the Many?, University of Cambridge, Cambridge 2009.

${ }^{2}$ L. Grzebień, S. Obirek (eds), Jezuici a kultura polska, WAM, Kraków 1993; Wkład jezuitów do nauki i kultury w Rzeczpospolitej Obojga Narodów i pod zaborami, ed. Irena Stasiewicz-Jasiukowa, WAM, Kraków 2004.

3 Z. Ogonowski, „Słowo wstępne do wydania polskiego”, in J. Lock, List o tolerancji, PWN, Warszawa 1963, p. IX.

4 J. Marshall, John Locke. Resistance, Religion, and Responsibility, Cambridge University Press, Cambridge 1994, p. 417: "Locke asserted in the two Vindicationes that Reasonableness had not included 'one word of Socinianism' conveniently ignoring the fact that he had been charged with Socinianism for a series of significant omissions. [...] The mental reservation in the case of Socinus was presumably that he had read the summary of Socinus' thought by his amanuensis, Volkel, and in case of Crell that he had read much more than a page.” 
However, only in recent years have they gained the status of universally accepted findings in the work of researchers in Western Europe and the United States. They can be reduced to two basic dimensions of Locke's thought: tolerance and rationality of religious beliefs. Although they are vividly present in the entire work of the British philosopher, they came to the fore in his late writings, published after many years of intensive contact with Socinian texts. ${ }^{5}$ The aim of this article is to point to these points of contact on the example of two texts: A Letter Concerning Toleration from $1689^{6}$ and, The Reasonableness of Christianity from $1695 .^{7}$ In the first we find echoes of the works of Jan Crell, On the freedom of conscience from $1632^{8}$ and Jonasz Schlechting, Against the Oppression of Conscience from $1654 .^{9}$ In contrast, the dissertation on the rationality of Christianity shows traces not only of the works of Fausto Sozzini ${ }^{10}$ himself, who drew attention to the need to reconcile Christianity with reason, but above all the treatise of Andrzej Wiszowaty On religion in accordance with reason, published posthumously in $1684^{11}$ in Amsterdam, and thus exactly when John Locke was there. Naturally, the listed texts do not exhaust all possible inspirations and it is not about their completeness at the moment, but rather about paying attention to the possible direction of further research.

First, a few words about reading John Locke. In the early 1950s John McLachlan drew attention to the contents of the rich collection of Socinian books in John Locke's private library. He was the first to write about "a significant number of Socinians." 12 However, only the publication of the library's content catalog in 1965 made researchers realize how urgent and well-oriented in Socinian literature the English philosopher was. ${ }^{13}$ Of course, the question may be asked whether the content of a private library is a sufficient argument indicating the presence of the influence of owned books on the views of its owner, especially if we are dealing with a clear denial of their existence. All we can do is to read the texts and draw conclusions ourselves.

${ }^{5}$ Ibidem, p. XV: "In the early 1660s Locke appears to hale been a believer in innate ideas as the foundation of much of morality and religion. He was an unequivocal opponent of religious toleration and of rights of resistance. [...] Between the early 1660s and the 1690s he changed from being a trinitarian who very probably held a strong view of Fall and original sin - in common with almost of all his contemporaries - to becoming at the least heterodox in his expressions about the Trinity and original sin and very probably in private an Unitarian heretic."

${ }^{6}$ J. Locke, A Letter Concerning Toleration and Other Writings, ed. Mark Goldie, Liberty Fund, Indianapolis 2000.

7 J. Locke, The Reasonableness of Christianity, Oxford University Press, Oxford 1999.

8 J. Crell, O wolności sumienia, PWN 1957.

9 J. Schlechting, Przeciwko uciskowi sumienia..., pp. 91-102.

${ }^{10}$ Faustus Socinus and His Heritage, ed. L. Szczucki, Polska Akademia Umiejętności, Kraków 2005.

${ }^{11}$ A. Wiszowaty, O religii zgodnej z rozumem, PWN 1960.

${ }^{12}$ H.J. McLachlan, Socinianism in Seventeenth-Century England, Oxford University Press, Oxford 1951, p. 326: "considerable extent of his collection of Sociniana."

${ }^{13}$ J. Harrison, P. Laslett, The Library of John Locke, Clarendon Press, Oxford 1971. 
As the author of the introduction to the Polish translation of Locke's A Letter Concerning Toleration Zbigniew Ogonowski notes, "Religious thought and the concept of Locke's tolerance are connected with the activities of Polish Socinians with many threads." 14 The same researcher of the first traces of Socinian influence makes him search for thinkers grouped around Viscount Falkland, i.e. "Tew Circle” already in the seventies of the seventeenth century. ${ }^{15}$ However, since the thirties of the seventeenth century, we can speak of the penetration of Socinian ideas into university environments and among the educated Anglican clergy. ${ }^{16}$

However, it was only during the voluntary exile in the Netherlands, to which Locke went in 1683, that influence significantly increased. You can find out about this by browsing through abundant correspondence from this period, especially to a close friend and publisher of Socinian, Armenian theologian Filip van Limborch. ${ }^{17}$ Their traces are visible in the aforementioned Treaty on Tolerance, which was only published in 1689 (although it was already written in 1685) in the Netherlands, so after Locke's return to England. It is worth adding that this treaty was published anonymously, because it contained content that could be interpreted as going beyond the boundaries of religious tolerated in England, namely, it clearly nudged... socinianism." ${ }^{18}$ However, comparisons with Socinian texts published thirty years earlier indicate that Locke, in his understanding of tolerance, set clear boundaries, namely excluding atheists and... Catholics. In fact, the Socinians, as another historian Jonathan I. Israel points out, represented a concept much broader than Locke's which should be linked to the fact that they were persecuted, just like the Jews, literally by everyone. ${ }^{19}$

The philosopher's situation was different, as he enjoyed the position we now call an influential intellectual, because he actively participated in the public life of the country both before leaving for the Netherlands in 1683 and returning six years later. However, it is not the specific political commitment that determines the meaning of John Locke, but his texts. And it is in them that one should look for a meeting with Polish brothers in mind.

In the book about John Locke, Zbigniew Ogonowski, commenting on A Letter Concerning Toleration of the hero of his book, notes: "Everything that Locke says

${ }^{14}$ Z. Ogonowski, Słowo wstępne do wydania polskiego, w: J. Locke, List o tolerancji, transl. Leon Jachimowicz, PWN, Warszawa 1963, p. VIII.

${ }^{15}$ Ibidem, p. XII.

${ }^{16}$ H.J. McLachlan, Socinianism..., p. 119: “The penetration of Socinian ideas into University circles and amongst the more scholarly clergy of the Church of England went on silently during the thirties and more openly during the forties of the seventeenth century."

17 J. Locke, The correspondence, 8 vols., ed. E.S. De Beer, Clarendo Pres Oxford, Oxford 1976-1989.

${ }^{18}$ Z. Ogonowski Locke, Książka i Wiedza, Warszawa 1972, p. 44.

19 J.I. Israel, A Revolution of the Mind. Radical Enlightenment and the Intellectual Origins of Modern Democracy, Princeton University Press, Princeton and Oxford 2010, p. 23. 
here has been repeated many times and often not less convincingly. In Poland, a few decades before the appearance of A Letter Concerning Toleration, Polish Socinians wrote about it in an amazingly similar way." ${ }^{20}$ For the first time, Ogonowski formulated the thesis about the possible influence of Polish Socinians in 1963 in the introduction to the Polish edition of A Letter Concerning Toleration, in which he drew attention to the environment of Locke's friends in Amsterdam, in which Socinian ideas were known and vividly commented. ${ }^{21}$ Interestingly, the thesis formulated half a century ago is confirmed today by both historians of the era and experts in the thoughts of the philosopher himself.

In the second part of the article, I suggest reading the Socinian texts first, which I will immediately compare with the relevant passage from John Locke's A Letter Concerning Toleration. Due to limitations, I can only discuss the problem of tolerance, while I leave the question of rational approach to religion for another occasion.

Let's start with the nearest text by Jonasz Schlechting. ${ }^{22}$ Published in 1654 after a request from Calvinist Dutch theologians to the authorities to stop what they called 'poisonous poison', i.e. Socinianism. In this letter, the Polish Socinian was more than 30 years ahead of John Locke's A Letter Concerning Toleration, and was even more uncompromising in understanding tolerance. Here are the most significant passages.

The first mentions who is subject to the authority of the state: "The state embraces and supports people of any origin and religion: even idolaters, even pagans, even heretics, and even apostates from Christ; and these only flourish the most by the multitude of inhabitants and the consent of the citizens, in which it makes no difference whether one is Trojan or Rutile [Virgil Aen. 10:08], if only everyone would live in harmony and show loyalty to the state which, among such great diversity, embraces them all equally."23 Similarly, the English philosopher, who emphasizes the benefits of tolerance not only of different Christian denominations, but also of different religions: "No man whatsoever ought therefore to be deprived of his Terrestrial Enjoyments, upon account of his Religion. Not even Americans, subjected unto a Christian Prince, are to be punished either in Body or Goods, for not embracing our Faith and Worship." ${ }^{24}$ This aspect is further emphasized elsewhere by the author Against the oppression of conscience.

In fact, in the second, Schlechting presents his concept of the relationship of political power to religious disputes: "Secular authorities, if they see disputes in the

20 Z. Ogonowski Locke, p. 136.

${ }^{21}$ J. Lock, List o tolerancji, Państwowe Wydawnictwo Naukowe, Warszawa 1963, pp. VII-XIII.

${ }^{22}$ J. Schlechting, Przeciwko uciskowi sumienia [Do prześwietnych i wielmożnych Stanów Holandii i Zachodniej Fryzji], in Myśl ariańska w Polsce w XVII wieku. Antologia tekstów, ed. Z. Ogonowski, Ossolineum, Wrocław1991, pp. 90-102.

${ }^{23}$ Ibidem, pp. 97-98.

24 J. Locke, A Letter Concerning Toleration..., p. 39. 
Church about the faith and dogmas of the Christian religion, have the responsibility, as secular power, not to support any party, to rule all according to these the rights themselves and to ensure that conflicting parties do not commit each other's crimes, and that church disputes do not lead to riots in the state; they should reject petitions directed to the authorities demanding the destruction of those who have different beliefs, and leave disputes initiated in the Church regarding the Church itself to be resolved by church tribunals. In this way, when refraining from the intervention of human strength and power, which is the main juice and food of weeds, the weed left to wither itself and only the truth will prevail."25 The separation of church and state competences is therefore obvious to Schlechting. Similarly for John Locke: “The Toleration of those that differ from others in Matters of Religion, is so agreeable to the Gospel of Jesus Christ, and to the genuine Reason of Mankind, that it seems monstrous for Men to be so blind, as not to perceive the Necessity and Advantage of it, in so clear a Light."”6

Jan Crell's treaty was written in 1632, i.e. during the interregnum after the death of Sigismund III Vasa, and was the voice in a lively debate about the relationship of political power to dissidents who, after a long, clearly favoring Catholic reign of Sigismund III, felt threatened in their rights. This was particularly true of Polish Brothers, who were fought unanimously by all Churches. Crell's line of argument refers to the Scriptures on the one hand and historical examples, especially from the first centuries of Christianity, on the other. Both clearly show that respect for a different understanding of what Christianity is in the spirit of the religion of Christ. Crell's text is a three-part intervention letter in defense of the rights of infidels already granted during the Sandomierz Confederation in 1573 (unfortunately the Polish Brothers were excluded from it, as previously from the Sandomierz Consent concluded between various Protestant denominations in 1570 . First, he writes about the need to preserve agreements, then points to examples from modern history when intolerance leads to religious wars, and finally in Part Three evokes arguments based on the Bible and church doctors. The whole ends with a request for peace. ${ }^{27}$

John Locke clearly advocates the need to separate state and church power and emphasizes that power should not force you to accept a specific religion. "Because the Care of Souls is not committed to the Civil Magistrate any more than to other Men. It is not committed unto him, I say, by God; because it appears not that God has ever given any such Authority to one Man over another, as to compel any one to his Religion." ${ }^{28}$ Perhaps there is an echo in this passage of the second part, On Freedom of Conscience, in which Crell points out the disastrous consequences of favoring one of the denominations (in this case Catholic) by the authorities in the

\footnotetext{
25 J. Schlechting, Przeciwko uciskowi sumienia, p. 100.

${ }^{26}$ J. Locke, A Letter Concerning Toleration..., p. 11.

$27 \mathrm{~J}$. Crell, $O$ wolności sumienia.

28 J. Lock, A Letter Concerning Toleration..., p. 13.
} 
event of a changed political system. Here is what can happen if we maintain the demand for one religion in the state [and this was postulated, for example, by the Jesuits]: "Therefore, if the argument we are trying to refute would be correct, the heretical authority would have to order that all Catholics should be expelled for peace. If Catholics did not like it, let them not like that the heretics weaker than them be expelled from their countries.”29

Of course, the political and religious contexts in which the cited texts were written and published were different. Nevertheless, it seems that John Locke took of the postulates of the Polish Brothers who demanded political neutrality towards various denominations (naturally demanding the right to profess their own version of Christianity) on the one hand and the right to religious freedom of each person on the other. This is evident above all in the author's reluctance to Christian reason for the theological arrogance of theologians of various denominations attacking him ruthlessly. Here is what he said about them: "I cannot but wonder at the extravagant arrogance of those Men who think that they themselves can explain things necessary to Salvation more clearly than the Holy Ghost, the Eternal and Infinite Wisdom of God."30

In the conclusion of A Letter Concerning Toleration, Locke pointed out how difficult it is to define the criteria for indicating who is a heretic or schismatic. Perhaps there is a defense of Socinianism, condemned by everyone at the time: "He that denies not any thing that the Holy Scriptures teach in express words, nor makes a Separation upon occasion of any thing that is not manifestly contained in the Sacred Text; however he may be nicknamed by any Sect of Christians, and declared by some, or all of them to be utterly void of true Christianity, yet indeed and in truth this Man cannot be either a Heretick or a Schismatick."31

However, I leave this matter for further research and discussion by referring to John Locke's texts on religion himself, superbly prepared and published in 2002 by Victor Nuovo. ${ }^{32}$ The same author published a book about the relationship between Christianity, antiquity and enlightenment in Locke's philosophy and theology a few years ago. ${ }^{33}$

\section{Literature}

Crell J., O wolności sumienia, PWN 1957.

Faustus Socinus and His Heritage, ed. L. Szczucki, Polska Akademia Umiejętności, Kraków 2005.

29 J. Crell, $O$ wolności sumienia, p. 38.

30 J. Lock, A Letter Concerning Toleration..., p. 66.

${ }^{31}$ Ibidem, p. 70.

32 J. Locke, Writings on Religion, ed. Victor Nuovo, Clarendon Press, Oxford 2002.

${ }_{33}$ V. Nuovo, Christianity, Antiquity, and Enlightenment. Interpretations of Locke, Springer, London-New York-Oxford 2011. 
Goody J., Renaissances. The One or the Many?, University of Cambridge, Cambridge 2009.

Grzebień L., Obirek S. (eds), Jezuici a kultura polska, WAM, Kraków 1993.

Harrison J., Laslett P., The Library of John Locke, Clarendon Press, Oxford 1971.

Israel J.I., A Revolution of the Mind. Radical Enlightenment and the Intellectual Origins of Modern Democracy, Princeton University Press, Princeton and Oxford 2010.

Lock J., List o tolerancji, Państwowe Wydawnictwo Naukowe, Warszawa 1963.

Locke J., A Letter Concerning Toleration and Other Writings, ed. Mark Goldie, Liberty Fund, Indianapolis 2000.

Locke J., The correspondence, 8 vols., ed. E.S. De Beer, Clarendo Pres Oxford, Oxford 1976-1989.

Locke J., The Reasonableness of Christianity, Oxford University Press, Oxford 1999.

Locke J., Writings on Religion, ed. Victor Nuovo, Clarendon Press, Oxford 2002.

Marshall J., John Locke. Resistance, Religion, and Responsibility, Cambridge University Press, Cambridge 1994

McLachlan H.J., Socinianism in Seventeenth-Century England, Oxford University Press, Oxford 1951.

Nuovo V., Christianity, Antiquity, and Enlightenment. Interpretations of Locke, Springer, London-New York-Oxford 2011.

Ogonowski Z. Locke, Książka i Wiedza, Warszawa 1972.

Ogonowski Z., Słowo wstępne do wydania polskiego, in J. Locke, List o tolerancji, transl. Leon Jachimowicz, PWN, Warszawa 1963.

Ogonowski Z., „Słowo wstępne do wydania polskiego”, in John Lock, List o tolerancji, PWN, Warszawa 1963.

Schlechting J., Przeciwko uciskowi sumienia [Do prześwietnych i wielmożnych Stanów Holandii i Zachodniej Fryzji], in Myśl ariańska w Polsce w XVII wieku. Antologia tekstów, ed. Z. Ogonowski, Ossolineum, Wrocław 1991.

Wiszowaty A., O religii zgodnej z rozumem, PWN 1960.

Wkład jezuitów do nauki i kultury w Rzeczpospolitej Obojga Narodów i pod zaborami, ed.

I. Stasiewicz-Jasiukowa, WAM, Kraków 2004. 